\title{
Kişilerarası Iletişim Sürecinde Toplumsal Cinsiyet Kimliği Kalıpyargılarının Belirlenmesi: İletişim Kaynağının Beden Dili Üzerinden Bir İnceleme
}

\author{
Derya Gül Ünlü (Arş. Gör. Dr.) \\ İstanbul Üniversitesi İletişim Fakültesi \\ derya.gul@istanbul.edu.tr \\ Orcid: 0000-0003-3936-7988
}

Başvuru Tarihi: 21.11.2018

Yayına Kabul Tarihi: 20.12.2018

Yayınlanma Tarihi: 21.01.2019

\section{Öz}

Toplumsal yaşama katıldığı andan itibaren bireyin kurduğu tüm bireylerarası ve gruplararası ilişkiler, onun toplumsal cinsiyet rolüne ve toplum tarafından kendisine verilen toplumsal cinsiyet kimliğine uygun bir biçimde gerçekleşmektedir. Kişilerarası iletişim sürecinde de, bireyin sahip olduğu toplumsal cinsiyet kimliğinin kurulan iletişimin şekillenmesi üzerinde önemli bir etkisi bulunmaktadır. Bununla birlikte, kişilerarası iletişim karşılıklı bir anlam inșa etme süreci olarak düşünüldüğünde, toplumsal yapının tanımladığı toplumsal cinsiyet rolleri ve bu rollere bağlı olarak ortaya çıkan toplumsal cinsiyet kalıpyargılarının iletişim süreci üzerindeki belirleyiciliğini yadsımak mümkün değildir. Çünkü bireylerin karşılaștıkları kişi ya da olayları anlamlandırma biçimleri, içinde bulundukları toplumsal yapıya ait değerler sisteminden ve bu değerler sistemi içerisinde yer alan kalıpyargılardan bağımsız değildir.

$\mathrm{Bu}$ bağlamda gerçekleștirilen çalışma, kişilerarası iletişim sürecinde kadın ve erkek iletişim kaynağının toplumsal cinsiyet kimliğine bağlı olarak ortaya çıkan kalıpyargıların beden diline ilişkin özellikler üzerinden belirlenmesi amacını taşımaktadır. Kalıpyargıların içeriğini belirleyebilmek amacıyla öncelikle bir pilot araştırma gerçekleştirilmiş ve içerisinde iletişim kaynağına ilişkin kalıpyargıları farklı düzeylerde niteleyen sıfatların bulunduğu bir listeye ulaşılmıştır. Sonrasında, kadın ve erkek iletişim kaynağı hakkındaki kalıpyargıları en yüksek düzeyde ifade eden ilk üç sıfat üzerinden bir anket çalışması gerçekleştirilmiştir. Anket çalışması aracılığıyla, kişilerarası iletişim sürecinde kadın ve erkek iletişim kaynağının çeşitli beden dili özelliklerine ilişkin hem kalıpyargılar hem de kalıpyargılara ilişkin duygu durumları ölçümlenmiştir. Çalışmanın son aşamasında ise, ulaşılan bulgular üzerinden, kadın ve erkek iletişim kaynağının beden diline ilișkin kalıpyargılara ve katılımcıların çeșitli demografik özellikleri üzerinden kalıpyargıların incelendiği karşılaştırmalı tablolar ve analizlere yer verilmiştir.

Anahtar Kelimeler: Toplumsal Cinsiyet, Beden Dili, Kalıpyargı, Kişilerarası İletişim. 


\title{
Determining Stereotypes about the Gender Identity in Interpersonal Communication Process: A Research On Body Language Of the Communication Source
}

\author{
Derya Gül Ünlü (PhD.) \\ İstanbul University Faculty of Communication \\ derya.gul@istanbul.edu.tr \\ Orcid: 0000-0003-3936-7988
}

Date Received: 21.11.2018

Date Accepted: 20.12.2018

Date Published: 21.01.2019

\begin{abstract}
From the moment an individual becomes a part of social life, all the interpersonal and intergroup relations take place according to individual's gender role and gender identity given by society to the individual. Individual's gender identity has an important role on the shaping of the communication established also in interpersonal communication process. On the other hand, when interpersonal communication is considered as a mutual process of constructing meanings, effect of gender roles defined by social structure and gender stereotypes resulting from these roles on communication process cannot be ignored. Because individuals' way of making sense of persons or events they encounter is not independent of the ethos of social structure, which they belong, and stereotypes in this ethos.

Conducted within this context, the study aims to determine stereotypes related to the gender identity of male and female communication source in interpersonal communication process. These stereotypes were analysed in terms of communication resource's body language characteristics. For the purpose of determining the content of stereotypes, first, a pilot research was conducted and a list, which includes adjectives that describes stereotypes related to communication source on different levels, was prepared. After this, a questionnaire study was carried out with three adjectives, which describe stereotypes about male and female communication source at the highest level. Through the means of the questionnaire, both stereotypes about the various features of male and female communication sources, and emotions related to stereotypes in the communication process were measured. In the last phase of the study, stereotypes related to male and female communication source, comparative tables and analyses conducted with various demographic characteristics of participants were presented based on the findings.
\end{abstract}

Keywords: Gender, Body Language, Stereotype, İnterpersonal Communication. 


\section{Giriş}

Kişilerarası iletişim, bireylerarasında gerçekleșen bir sosyal etkileşim sürecine işaret etmektedir. Bu sosyal etkileşim sürecinde, bireyler çeşitli kodları birbirlerine aktararak karşılıklı etkileşim kurmaktadırlar. Diğer yandan bu etkileşim süreci bireylerin sadece birbirlerine çeşitli kodları ya da simgeleri iletmeleri kadar basit değildir. Çünkü bu etkileşim sürecini şekillendiren pek çok farklı unsur bulunmaktadır. Bireyin karşısındakiyle gerçekleştirdiği, kişilerarası iletişim, onun sahip olduğu kültürel arka plan, geçmiş deneyimleri, çevresini algılama biçimi ya da tutumları gibi birçok bileşenin etkisi altındadır. Bu çerçevede, hem hedef hem de kaynak olan öznelerin, kişisel özelliklerini iletişim sürecine dahil ettikleri düşünüldüğünde, toplumsal cinsiyet kimliğinin de iletişim süreci içerisinde önemli bir rol oynadığını söylemek mümkündür.

Kişilerarası iletişim karşılıklı bir anlam inşa etme sürecini ifade etmektedir. $\mathrm{Bu}$ bakımdan toplumsal yapı tarafından kadın ve erkek için 'içeriği belirlenmiş' toplumsal cinsiyet rolleri de söz konusu anlamın inşa edilmesinde önemli bir rol oynamaktadır. Çünkü toplumsal cinsiyet rolü, bireyin sahip olduğu biyolojik cinsiyetinin yanı sıra buna uygun olarak yerine getirmesi gereken davranışlar bütününe yönelik bir beklentiyi de içermektedir. Kişilerarası iletişim süreci içerisinde bireyin bu söz konusu beklentiyi karşılayamaması, bireyler arasındaki anlam üretimini olumsuz etkilemekte ve çeşitli iletişim engellerinin ortaya çıkmasına neden olmaktadır.

Bu bağlamda, bir kişilerarası iletişim engeli olarak ortaya çıkan kalıpyargıların en önemlileri arasında, iletişim kaynağının toplumsal cinsiyet kimliğine dayananları bulunmaktadır. Bu kalıpyargılar, toplumsal cinsiyet rolleriyle bağlantılı olmakta ve birey toplumsal cinsiyet kimliği nedeniyle, birçok alanda olduğu gibi, kişilerarası iletişim sürecinde de çeşitli engellerle karşılaşabilmektedir. Çünkü kalıpyargılar ve beraberinde ortaya çıkan önyargılar dolayısıyla, taraflar arasında kurulan iletişim ortak anlam üretim süreci olmaktan çok bir çatışmaya dönüşmektedir. Bu bakımdan araştırma kapsamında öncelikle kişilerarası iletişim sürecinde toplumsal cinsiyet kimliğinin yeri ele alınarak, bu süreçte karşılaşılan toplumsal cinsiyet kimliği kalıpyargılarına ve çeşitli beden dili özelliklerine ilişkin kalıpyargıların bireyin cinsiyetine bağlı olarak nasıl farklılık gösterdiğine değinilecektir. Çalışmanın araștırma bölümünde ise, kadın ve erkek iletişim kaynağının toplumsal cinsiyet kimliğine bağlı olarak beden diline ilişkin özelliklerine atfedilen kalıpyargılar ve bu kalıpyargıların duygu durumları ortaya koyulmaya çalışılacaktır.

\section{Kişilerarası İletişim ve Toplumsal Cinsiyet Kimliği}

Kişilerarası iletişim kavramını, temel olarak "karşılıklı iletişimde bulunan bireylerin, bilgi/sembol üreterek birbirine aktarması" biçiminde ifade etmek mümkündür (Dökmen, 2006, 23). Daha kapsayıcı bir tanımlamada ise, kişilerarası iletişim; "iki kişi arasında, genellikle kendiliğinden ve teklifsiz olarak gerçekleşen, iletişimin gerçekleşmesi sırasında genellikle aynı fiziksel ortamda bulunan tarafların nöbetleşe olarak iletişimde bulunması ve sürekli geribildirim verdikleri iletişim" olarak aktarılmıştır (Mutlu, 1998, 208-209).

Gürüz ve Eğinli $(2011,54)$, kişilerarası iletişim kavramını; "iki kişi arasında kurulan etkileşim sonucunda anlam yaratılması ve anlamın paylaşılması süreci" olarak tanımlamaktadır. Yazarlara göre, bu tanımın içerisinde süreç, mesaj etkileşimi, anlam paylaşılması olmak üzere üç bileşen bulunmaktadır. Buna göre, kişilerarası 
iletişim bir süreçtir, yani sürekliliği olan, sonu bulunmayan, coşkulu bir aktivite olup sürekli değişmektedir. İki kişi arasında kişilerarası iletişim başladığında, başlangıcı ve sonucu tanımlanamaz ve geri çevrilemez bir süreç ortaya çıkmaktadır. Diğer bir nokta ise, mesajların değişimidir. İki kişi arasında karşılıklı olarak sözlü ve sözsüz mesajların gönderilmesi ve alınması söz konusudur. Hem sözlü hem de sözsüz mesajlar, bir daire olarak etkileşimde bulunmakta, iletişimde bulunanları etkilemektedir. Ancak mesajların kişilerarasında aktarılması yeterli değildir, mesajların anlam yaratması ve anlamların paylaşılması gerekmektedir. Bununla birlikte, kişilerarasında iyi ya da kötü ilişkisel deneyimlerin var olması, mesajların anlamlandırılmasını da etkilemektedir.

Gürüz ve Eğinli'nin tanımlamasından yola çıkılarak, kişilerarası iletişim karşılıklı bir anlam inşa etme süreci olarak düşünüldüğünde, toplumsal yapının tanımladığı toplumsal cinsiyet rolleri ve bu rollere bağlı olarak ortaya çıkan toplumsal cinsiyet kalıpyargılarının iletişim süreci üzerinde önemli bir etkisinin bulunduğunu söylemek mümkündür. Çünkü bireylerin karşılaştıkları kişi ya da olayları anlamlandırma eğilimleri, onların içinde bulundukları toplumsal yapıyla yakın bir ilişki içerisindedir. Bireyin karşısındakiyle kurduğu iletişiminin içeriği, üyesi bulunduğu toplumsal yapının kültürel arka planı, cinsiyete bakışı ya da önyargılarından bağımsız değildir.

Toplumsal cinsiyet kimliği, kadınlık ve erkekliğe ilişkin toplumsal yapının yüklediği anlamlar ve beklentileri ifade etmektedir. Toplumsal cinsiyet, bireyin belli bir cinsten olduğuna ilişkin bilgiye, bu bilgi dahilinde olmak üzere toplumsal düzeyde bireyden beklenenlere ve toplumda bireye biçilen konuma işaret etmektedir (Vatandaş, 2007, 35-36). Kadın ve erkek arasındaki rol farklılıkları ise, cinsiyet özellikleriyle birlikte cinsiyete yönelik olarak kültür tarafından öngörülen kalıpyargıların ve rollerin öğrenilmesinden kaynaklanmaktadır. Çünkü cinsiyet rolü, kültür içerisinde tanımlanmış, öngörülmüş bir içeriğe sahiptir ve bireylerin sahip olduğu cinsiyete ilişkin toplumun beklentilerini ifade eden alışkanlık, hal, tavır ve değerleri içinde taşımaktadır (Ersoy, 2009, 213-215).

$\mathrm{Bu}$ bağlamda değerlendirildiğinde, toplumsal cinsiyet ilişkilerinin dayattığ cinsiyetlerarası farklılaşma ve eşitsizliğin, iletişim süreci içerisindeki kaynak ve hedefin referans çerçevesinin birbirinden uzaklaşmasına neden olduğunu söylemek yanlış olmayacaktır. Kişilerarası iletişim sürecinin, eșit konumda bulun(a) mayan bireyler arasında gerçekleşmesi, kaynağın gönderdiği mesajın hedefe ulaş(a)mamasını, ulaşması durumunda ise istenen etkiyi yarat(a)mamasını ve sonuç olarak iletişim sürecinin hedeflenenden farklı sonuçlanmasını da beraberinde getirmektedir.

\subsection{Kişilerarası İletişim Sürecinde Toplumsal Cinsiyet Kimliği Kalıpyargıları}

Kalıpyargı kavramını, "bir sosyal grup üyeleriyle ilgili olarak algılayıcının sahip olduğu beklentiler seti" (Hamilton, 1979, 65) ya da "bir kategori ya da bir sosyal grubun üyeleriyle ilişkilendirilen, onlara atfedilen ve onları tanımlayan özellikler" (Stangor ve Lange, 1994, 361) olarak ifade etmek mümkündür. Kalıpyargı, ortak bir kültürel özellik, yaşam tarzı ve eylem içinde bulunan kişileri, bu ortak özelliklerin kafamızda uyandırdığı çağrışımlarla birleştirerek oluşturduğumuz imgeler aracılığıyla algılamak anlamına gelmektedir. Birey, bu tür ortaklaşa özelliklere sahip olan kişileri sonrasında tek tek bireyler halinde de gördügünde kalıpyargılama sürecindeki yargıları, onun tüm değerlendirmelerine temel 
oluşturmaktadır. Buna göre bütün bir kategori, o anda gözlemlediğimiz bireyin gerçek durumu ne olursa olsun, onun değerlendirilmesi için bir süzgeç görevi görmektedir. Bu süzgeç içinde, toplumsal olarak belirli özelliklere sahip kişileri yerleştirdiğimiz kategoriler, bu özellikler hakkında daha önceden yaşadığımız deneyimlerle oluşan değer yargılarımız, bireyin ve kendimizin o andaki durumu ve çıkarı, eylemin niteliği ve bütün bir toplumsal yapı bulunmaktadır. Bireylerin algılanmasıyla birlikte ortaya çıkan bu 'normlar', kişilerarası ilişkileri belirleyen bir işlev görmektedir. Ayrıca bireyin algılamaya yönelik zihinsel işlemleri de, toplumsal normların biçimlendirmesi ve kalıpyargılama süreci içerisinde gerçekleşmektedir (İsen ve Batmaz, 2006, 214-215). Dolayısıyla bireyin bilişsel düzeyde sahip olduğu kalıpyargıların içeriğinin ve duygu durumunun bilinmesi, kişilerarası iletişim sürecinde karşılaşılabilecek engellerin ya da yaşanabilecek çatışmaların anlaşılması açısından da büyük önem taşımaktadır.

Kişilerarası iletişim sürecinde karşılaşılabilecek engellerden biri de kaynağın ya da hedefin toplumsal cinsiyet kimliğine bağlı olarak ortaya çıkan kalıpyargılardır. $\mathrm{Bu}$ kalıpyargılar, toplumsal cinsiyet rolleriyle bağlantılı olmakta ve birey toplumsal cinsiyet kimliği nedeniyle, birçok alanda olduğu gibi, kişilerarası iletişim sürecinde de çeşitli engellerle karşılaşabilmektedir. Toplumsal cinsiyet kimliğine dayalı olarak ortaya çıkan kalıpyargı biçimlerini genel olarak üç ana başlık altında sınıflandırmak mümkündür (Adaçay, 2014, 19-20):

- Toplumun bir grup olarak kadınların ve bir grup olarak da erkeklerin göstermelerini bekledikleri özelliklere yönelik toplumsal cinsiyet kalıpyargıları,

- Kadın ve erkek için uygun görülen rol ve faaliyetlerdeki cinsiyet rollerine ilişkin kalıpyarglar,

- Bir cinsiyeti diğer cinsiyete oranla daha az ya da daha çok nitelediği düşünülen özellikler ise cinsiyet özelliklerine ilişkin kalıpyargılar olarak adlandırılmaktadır.

Bununla birlikte, toplumsal cinsiyet kimliğine ilişkin kalıpyargıların diğer kalıpyargı biçimlerinden farklılık gösterdiğini de eklemek gerekmektedir. Toplumsal cinsiyet kimliğine ilişkin kalıpyargılar, bireylere betimsel reçeteler sunmaktadır. Bu kalıpyargıların betimsel yanı, o kalıpyargının ait olduğu grubun tipik bir üyesinin neye benzediğiyle ilişkili olarak, insanların zihinlerindeki tanımlamalardır (örneğin; kadına duygusal, zayıf, bağımlı, pasif vb. özelliklerin yüklenmesi gibi). Reçetesel öğesi ise, o grubun üyelerinin neler yapmaları, nasıl davranmaları gerektiğini dikte eden yanını ifade etmektedir (örneğin; kadının kişilerarası ilişkilerde becerikli olması, pasif ve yumuşak başlı olması gerektiğinin beklenmesi gibi). Bu reçetesel yan, diğer bir deyişle bu gereklilikler, toplumsal cinsiyet kimliği kalıpyargılarında, çok merkezi ve çok güçlü bir yer tutmaktadır. Çünkü toplumsal cinsiyet kimliği hakkındaki kalıpyargılar, hem kadınların hem de erkeklerin davranışlarını sınırlandırmaktadır. Bu gereklere uyulmaması, çok dikkat çekicidir ve genellikle olumsuz algılanmakta, önyargılı tutumların ortaya çıkmasına neden olmaktadır. Sonrasında ise, güçlü bir cinsiyet ayrımcılığıyla karşılașılmaktadır (Dökmen, 2012, 105-106).

Toplumsal cinsiyet kalıpyargılarını, toplumun bir grup olarak kadınlardan ve bir grup olarak erkeklerden beklediği bazı davranışlar ve özellikler olarak ifade etmek mümkündür. Bu beklentilere uygun özellik ve davranışlara ilişkin kalıpyargılar olumlu ya da nötr içeriklere sahip olurken, uygun görülmeyen özellikya da davranışlar ise olumsuz içerikli kalıpyargıları ortaya çıkarmaktadır. Bu bakımdan söz konusu 
kalıpyargıların hem kadınların hem de erkeklerin davranışlarını sınırlandırdığını da söylemek yanlış olmayacaktır. Çünkü kadın ve erkek cinsiyetine atfedilmiş çeşitli özellikler dolayısıyla ortaya çıkan bu kalıpyargıların belirli ortak özellikler çerçevesinde iki temel kümeye ayrıldıkları görülmektedir (Deaux ve Lewis, 1982, 992). Bu bağlamda, toplumsal cinsiyet kimliğine ilişkin kalıpyargıların belirlenmesi amacıyla, Broverman ve arkadaşları (1972, 63) tarafindan gerçekleştirilen bir çalışmada, katılımcılardan kadınlar ve erkekler hakkında tipik olduklarını düşündükleri özellikleri yazmaları istenmiştir. Çalışma sonucunda, katılımcıların, kadın ve erkekler için tipik olan özellikler üzerinde bir fikir birliğinin bulunduğu tespit edilmiştir. Araştırmacılar katılımcılar tarafından ifade edilen özellikleri kümelemiş ve kadınlarla ilgili nitelikleri içeren küme, sıcaklık-etkileyicilik kümesi (örneğin; kaba bir dil kullanmayan, konuşkan, nazik, dış görünüşüyle ilgili, güvenlik ihtiyacı olan, şefkatli, duygularını ifade eden gibi); erkeklerle ilgili nitelikleri içeren küme ise, yeterlilik kümesi (saldırgan, bağımsız, duygusal olmayan, baskın, rekabetçi, mantıklı, lider, hırslı, dış görünüşe önem vermeyen, kolay incinmeyen gibi) adı altında gruplandırılmıştır. Benzer farklılaşmalara gerçekleştirilen çok sayıda çalışmada da (Rosenkratz, 1968; Spence ve diğerleri, 1975; Williams ve Best, 1992; Williams ve diğerleri, 1999) rastlamak mümkündür. Diğer taraftan, toplumsal cinsiyet kimliğine ilişkin kalıpyargıların, genellikle tüm dünyada birbirine benzer içeriklere sahip olsalar da evrensel olmadıklarının da belirtilmesi gerekmektedir. Kalıpyargıların içerikleri, o toplumun eğitim düzeyi, tarihi geçmişi, bulunduğu coğrafi konumu ya da kültürel özelliklerine bağlı olarak farklılaşabilmektedir.

Toplumsal cinsiyet kalıpyargılarının bir başka özelliği de diğer cinsiyetten bireylerle olan yakın ilişkiler dolayısıyla çok karmaşık bir yapıya sahip olmalarıdır. Çünkü kadın ve erkek birlikte pek çok yaşantıyı paylaşmaktadır. Eş, anne, baba, kardeş, sevgili, iş arkadaşı vb. olarak paylaşılan yaşantılar, bireylerin diğer cinsiyet hakkında çok karmaşık beklentiler geliştirmelerine yol açmaktadır. Bazen bu etkileşim diğer cinsiyet hakkında, özellikle kadınlar hakkında, bazı alt kategoriler (örneğin; kadın doktor, kadın polis gibi) geliştirilmesine de neden olabilmektedir. Bu alt kategoriler, bir cinsiyete ilişkin kalıpyargıların o cinsiyetteki üyeye tam uymadığı durumlarda ortaya çıkmaktadır. Bu gibi durumlarda, bir kalıpyargının dikte ettiği niteliklerin o grubun tüm üyeleri için geçerli olmadığı ve/veya yanlış olduğu sonucunu doğurması ve kalıpyargının değişmesi beklenebilir. Ancak toplumsal cinsiyet kimliğine ilişkin kalıpyargılarda sonuç böyle olmamakta; o cinsiyete ilişkin kalıpyargıların özü aynı kalmaktadır (Dökmen, 2012, 106). Örneğin; kadınların çok narin ve güç gerektiren işleri yapamayacaklarını düşünen birey, arabasının lastiğini değiştiren kadın bir taksi şoförüyle karşılaştığında bu durumun tüm kadınlar için geçerli olabileceğini değil, sadece o kadına özgü olduğunu düşünmektedir. Bu bağlamda değerlendirildiğinde, toplumsal cinsiyet kimliğine dayanan kalıpyargıların kişilerarası iletişim süreci için de önemli belirleyiciler olduğunu söylemek yanlış olmayacaktır.

\section{Kişilerarası İletişim Sürecinde İletişim Kaynağının Beden Diline Iliş̧kin Kalıpyargılar}

Sözsüz iletişim, konuşulan dilin dışında, jestler, mimikler ya da diğer dilsel olmayan işaretler (giyim kuşam, seçilen renkler, mekânsal düzenlemeler gibi) aracılığıyla karşı tarafa gönderilen niyetli ya da niyetli olmayan iletileri kapsamaktadır. Sözsüz iletişimin önemli bir kesitini oluşturan jestler, mimikler, giyim kuşam gibi insan bedeni aracılı iletişim beden dili olarak da adlandırılmaktadır (Güngör, 2011, 38). Bu bağlamda, özellikle bireyin beden diline ilişkin anlamlandırmalarını 
toplumsal cinsiyet açısından da ele almak önem taşımaktadır. Çünkü beden dilinin anlamlandırmalarına yönelik tahminler, bireyin öğrendiği toplumsal cinsiyet rolü kalıpyargılarına dayanmaktadır (Blank ve diğerleri, 1981; Hall, 1978).

Bireylerin beden diline ilişkin farklılașmalarının büyük bir çoğunluğunun toplumsal cinsiyet farklılığına dayandığı görülmektedir. Buna göre, kadınların erkeklere nazaran daha samimi ve kibar görüldüklerini, erkeklerin kadınlara göre yüksek sesli konuşmak, başkalarını işaret etmek, karşısındakine dik bir biçimde bakmak gibi dominant davranışları daha fazla tercih ettiklerini söylemek mümkündür (Diekman ve Eagly, 2000; Eagly ve Johanessen-Schmidt, 2001). Ayrıca toplumsal yaşam içerisinde erkeklerin saldırganlık ya da rekabetçilik gibi dominant davranışlarının kadınlara nazaran daha yerleşik olduğu da belirtilmektedir (Carli, 2001, 732). Buna ek olarak, kadınların erkeklere göre karşılarındaki bireye daha fazla dokunma eğiliminde oldukları ve yine kadınların erkeklere nazaran kendileriyle aynı cinsiyete sahip bireylere daha fazla dokunma davranışında bulunduklarından da bahsetmek mümkündür (Stier ve Major, 1984, 440).

Kadın ve erkeklerin sözel olmayan davranışlarda da farklılaştıklarından ve bu farklılığın statüsü yüksek ve düşük insanlardakiyle benzerlik gösterdiğinden bahsedilmektedir. Buna göre, kadınların sözel olmayan davranışlarda erkeklerden daha duyarlı olmaları; onların toplum içinde daha düşük statüde olmalarının bir sonucudur. Çünkü düşük statüdeki insanlar, yüksek statüdeki insanların yüz ifadelerine daha duyarlı olmak ve kendilerini buna göre ayarlamak durumundadırlar. Dolayısıyla statüsü düşük bireyler davranışlarında daha temkinlidirler, daha gergin bir vücut duruşuna sahiptirler, fiziksel mesafeyi daha çok korurlar, diğerlerine daha az dokunurlar, gözlerinin içine bakmadan, kaçırarak ve izleyerek göz temasında bulunurlar, daha çok gülümserler, duygularını gösterirler ve kendilerini daha çok açarlar. Kadınların da erkeklere nazaran tıpkı bu düşük statülü bireyler gibi davrandıkları belirlenmiştir. Sonuç olarak, sözel olmayan davranışları kullanmada erkeklerin statüsü yüksek bireyler gibi, kadınların ise statüsü düşük bireyler gibi davrandıklarını söylemek mümkündür (Dökmen, 2012, 165).

Diğertaraftan,Deauxve Major $(1987,369)$ toplumsalcinsiyetkimliğiyleilişkilendirilen tüm davranışların değerlendirenin algısı, değerlendirdiği bireyin kişisel özellikleri ve duruma özgü değişkenlerden bağımsız olmadığının da altını çizmektedirler. Bu bakımdan toplumsal cinsiyet kimliğiyle ilişkili olarak, çeşitli beden dili özelliklerine yönelik yorumlamalar da söz konusu dinamikler değiştiğinde farklılaşabilir.

\section{Amaç ve Yöntem}

Araştırma, kişilerarası iletişim sürecindeki ilk karşılaşma anında iletişim kaynağının bedendilineilişkinkalıpyargılarınnelerolduğunun tanımlanmasıvebukalıpyargıların kaynağın toplumsal cinsiyet kimliğine bağlı olarak farklılık gösterip göstermediğinin belirlenmesi amacını taşımaktadır. Ayrıca söz konusu kalıpyargılara ilişkin duygu durumlarının neler olduğunun ortaya koyulması da çalışmanın amaçları arasında yer almaktadır. Bu doğrultuda, çalışmada cevaplanması hedeflenen ana amaç sorusu ise şöyledir:

AS. Kişilerarası iletişim sürecinde kaynağın beden diline ilişkin kalıpyargılar nelerdir? Bu kalıpyargılar kaynağın toplumsal cinsiyet kimliğine bağlı olarak farklılaşmakta mıdır? Bu kalıpyargılara yönelik duygu durumları nelerdir? Bu kalıpyargılar, değerlendirenin cinsiyetine bağlı olarak farklılık göstermekte midir? 
Bununla birlikte, iletişim kaynağının beden dili özelliklerine ilişkin değişkenlerin sayısı göz önünde bulundurulduğunda, yukarıda yer alan ana araştırma sorusunun detaylandırılması ve sınırlandırılması gerekli görülmüştür. Bu bağlamda, kadın ve erkek iletişim kaynağının beden diline ilişkin kalıpyargıların belirlenebilmesi amacıyla cevaplanması hedeflenen alt amaç soruları aşağıdaki gibidir:

AS1.Kişilerarası iletişim sürecinde kadın ve erkek iletişim kaynağının beden mesafesine (yakınlık/uzaklık/bedensel temas) ilişkin kalıpyargılar nelerdir? Bu kalıpyargılara yönelik duygu durumları nasıldır? Bu kalıpyargılar, değerlendirenin cinsiyetine bağlı olarak farklılık göstermekte midir?

AS2. Kișilerarası iletişim sürecinde kadın ve erkek iletişim kaynağının mimiklerine (gülme/göz teması/somurtma/ağlama) ilişkin kalıpyargılar nelerdir? Bu kalıpyargılara yönelik duygu durumları nasıldır? Bu kalıpyargılar, değerlendirenin cinsiyetine bağlı olarak farklılık göstermekte midir?

AS3.Kişilerarası iletişim sürecinde kadın ve erkek iletişim kaynağının jestlerine (jestleri kullanma/kullanmama) ilişkin kalıpyargılar nelerdir? Bu kalıpyargılara yönelik duygu durumları nasıldır? Bu kalıpyargılar, değerlendirenin cinsiyetine bağlı olarak farklılık göstermekte midir?

AS4.Kişilerarası iletişim sürecinde kadın ve erkek iletişim kaynağının bedeninin duruşuna (yürüme/oturma) ilişkin kalıpyargılar nelerdir? Bu kalıpyargılara yönelik duygu durumları nasıldır? Bu kalıpyargılar, değerlendirenin cinsiyetine bağlı olarak farklılık göstermekte midir?

Söz konusu araștırma sorularını cevaplandırabilmek amacıyla gerçekleștirilen çalışma, soru formu aracılığıyla uygulanan betimsel nitelikteki bir alan araştırmasıdır. Soru formu içerisinde, katılımcılara, tamamlama yöntemiyle verili ifadeleri eşleştirmelerinin istendiği projektif bir test uygulanmıştır. Projektif test yönteminde; deneğe belirsiz uyarıcılar verilerek, deneğin bunlara yönelik tepkide bulunması istenmektedir. Testin amacı deneğe açıkça bildirilmediğinden, verilen yanıtların deneğin bilinçdışı istek ve duygularını, dış dünyayı algılama biçimini yansıtacağı varsayımı kabul edilmektedir (Akkoyun, 1983, 399).

Pilot araștırma kapsamında uygulanan projektif testi ise, bir tamamlama testi olarak ifade etmekmümkündür. Projektifbir testolan tamamlamayönteminde; deneğeyarım bırakılmış bir uyarıcı verilerek, deneğin bunu uygun gördüğü şekilde tamamlaması istenmektedir (Akkoyun, 1983, 403). Bununla birlikte, soru formu uygulanmadan önce, soru formunda yer verilecek uyarıcı ve sıfatların belirlenebilmesi amacıyla pilot bir saha çalışmasının uygulanması gerekli görülmüştür. Böylelikle soru formunda yer alacak uyarıcı ve sıfat listelerinin katılımcılar tarafından belirlendiği ve bu sıfatların toplumsal yapının değerlerini yansıtacak içeriğe sahip olduğu bir veri toplama aracının geliştirilebilmesi hedeflenmiştir.

\subsection{Veri Toplama Aracının Geliştirilmesi}

Pilot araştırma için hazırlanan soru formunda, katılımcıların demografiközelliklerine yönelik soruların (cinsiyet, yaș, medeni hal, eğitim durumu) yanı sıra, katılımcıların eşleştirebileceği beden diline ilişkin çeşitli özellikleri içeren bir uyarıcı listesi ve sıfat listesi sunulmuştur. Beden dili özellikleri için; mesafe (yakınlık/uzaklık/bedensel temas), mimikler (gülme/göz teması/somurtma/ağlama), jestler (jestleri kullanma/ kullanmama) ve bedeninin duruşu (yürüme/oturma) değişkenleri seçilmiştir. Sıfat listesi için ise, 32 maddeli sıralandırılmış bir sıfat listesi hazırlanmıştır. Oluşturulan bu listede yer verilen sıfatlar, daha önce hem çeşitli kişilik testleriyle ilgili çalışmalar 
(Somer, 1998; Matthews ve diğerleri, 1990) hem de kalıpyargı araştırmalarındaki (Katz ve Braly, 1933; Gilbert, 1951; Karlins ve diğerleri, 1969; Best ve diğerleri, 1977; Eagly ve Kite, 1987; Williams ve diğerleri, 1999; Madon ve diğerleri, 2001) testlerde kullanılan sıfatların incelenmesi ve araştırmanın amacına uygun görülenlerin listeye dahil edilmesi şeklinde ortaya çıkmıştır. Ayrıca zaman aşımına uğramış bir sıfat listesinin kullanılmaması amacıyla da incelenen çalışmalardan seçilen bazı sıfatların ifade biçimleri değiştirilmiştir.

Kişilerarası iletişim sürecinde iletişim kaynağının toplumsal cinsiyet kimliğine ilişkin, kalıpyargıların duygusal boyutunun da ortaya koyulması çalışmanın hedefleri arasında yer almaktadır. Bu bakımdan kalıpyargıların duygusal boyutunu belirleyebilmek amacıyla, pilot araştırma formuna dahil edilen sıfatların olumlu, olumsuz ve nötr duyguları karşılayacak bir biçimde verilmesi gerekli görülmüştür. Kadın ve erkeğe ilişkin özellikler ise, birbirlerine göre karşı cinsi ifade etmeleri dolayısıyla, genellikle, karşı cinsin sahip olduğu özelliklerin zıddı özelliklerle tamamlanmaktadır. Örneğin; kadın cesur olmayandır, kaba saba konuşmayan ve davranmayandır; erkek de duygulu olmayandır, cici bici, narin ve nazik davranmayandır (Dökmen, 2012, 104). Bu doğrultuda çalışma kapsamında, sıfat listesi içerisinde yer alan sıfatların birbirlerinin zıttı içeriklere sahip olmalarına dikkat edilmiştir. Nötr sıfatlar ise, çalışmanın ilerleyen bölümlerinde, katılımcıların yaptıkları eşleşmeler doğrultusunda, aldıkları olumlu ya da olumsuz duygu durumları bağlamında değerlendirilmiştir. Dolayısıyla pilot araștırmanın soru formunda yer verilen olumlu, olumsuz ve nötr içerikli 32 sıfattan oluşan liste şöyle olmuştur: olumlu sıfat listesi; çekici, kibar, iddialı, dışa dönük, samimi, edepli, namuslu, akıllı, eğlenceli, normal, mütevazi, dirençli, mantıklı. Olumsuz sıfat listesi; itici, kaba, çekingen, içe dönük, içten pazarlıklı, müstehcen, baştan çıkarıcı, saf, sıkıcı, anormal, gösterişi seven, narin, kendini beğenmiș, kendine güvensiz, duygusal. Nötr sıfat listesi; kadınsı, erkeksi, modern, geleneksel.

Diğer yandan Harlak'ın $(2000,126)$ da değindiği gibi, katılımcıların bireysel farklılıklarının ve bilişsel repertuar çeşitliliğinin çalışmaya dahil edilebilmesi amacıyla 30 sıfattan oluşanlisteye bir de açıkuçlu sıfatkutucuğu eklenmiş, böyleliklekatılımcıya listede bulunmayan sıfatı ya da sıfatları ekleme imkanı tanınmıștır. Böylelikle pilot araştırma formu içerisinde katılımcılardan iletişim kaynağının çeşitli özellikleri hakkında verilen uyarıcıları, 31 maddeli bir sıfat listesiyle eșleștirmeleri istenmiștir. Ayrıca Devine ve Elliot'un $(1995,1139)$ da vurguladığı gibi, katılımcıların her bir uyarıcıya ilişkin sahip olduğu kalıpyargı biçimlerinin içeriğinin ve yoğunluğunun aynı olmayacağı gözetilerek, eşleştirme içerisinde seçilmesi gereken sıfat sayısıyla ilgili bir kısıt koyulmamıștır. Katılımcılara, kendilerine verilen uyarıcılara uygun gördükleri sıfatları istedikleri kadar seçebilme imkanı sunulmuştur. Son olarak, çalışmada yer alan uyarıcı ifadelerden bazılarının (güzellik/çirkinlik/çekicilik/ yakışıklılık gibi), her katılımcı için göreceli olduğu düşünülerek, yönergede katılımcıların kendilerine sunulan ifadeleri başat bir güzellik/çirkinlik/çekicilik vb. anlayışı çerçevesince değerlendirmeleri istenmiştir.

Son hali verilen soru formu, öncelikle 15 katılımcıya uygulanmış ve 15 katılımcı üzerinden ulaşılan bulgular aracılığıyla çalışmada gerekli görülen düzeltmeler yapılmıştır. $\mathrm{Bu}$ aşamada gerçekleștirilen düzeltme; sıfat listesine iki adet daha sıfatın eklenmesi (mütevazi ve gösterişi seven) olmuştur. Dolayısıyla son halini alan soru formunda 33 sıfattan oluşan sıralandırılmış liste katılımcılara sunulmuştur. 
Pilot araştırma soru formu, 173 katılımcıya uygulanmış, 14 soru formu hatalı cevaplandırılmalar nedeniyle analiz dışında bırakılmış, 159 soru formuna verilen cevapların frekansı alınmıştır.

Buna göre, pilotaraştırmada yer alan 159 katılımcının demografik özellikleri şöyledir: Katılımcıların \%50,3'ü (80 kişi) kadın, \%49,7'si (79 kişi) erkektir. Katılımcıların \%17'si (27 kişi) 18-24, \%34'ü (54 kişi) 25-34, \%35,4'ü (56 kişi) 35-44, \%11,5'i (18 kişi) 45-54, \%2'si (3 kişi) 55-64 yaş aralığındadır. Katılımcıların \%50,3'ü (80 kiși) evli, \%49,7'si (79 kişi) bekardır. Katılımcıların \%37,7'si ilkokul ve lise (60 kişi), \%44,6’sı (71 kişi) ön lisans ve lisans, \%16,3'ü (26 kişi) yüksek lisans ve doktora programı mezunudur.

Kadın iletişim kaynağının beden diline ilișkin en yüksek frekansı alan kalıpyargılar sırasıyla şöyledir: konuşurken yüksek sesle kahkaha atan kadın için itici, dışa dönük, kendini beğenmiş; konuşurken sessizce gülümseyen kadın için kibar, normal, çekici; konuşurken yakın duran kadın için samimi, itici, normal; konuşurken uzak duran kadın için çekingen, içe dönük, normal; konuşurken karşısındakine dokunan kadın için samimi, itici, dışa dönük; konuşurken göz teması kuran kadın için samimi, normal, iddialı; konuşurken göz teması kurmayan kadın için kendine güvensiz, çekingen, içe dönük; somurtan kadın için sıkıcı, itici, normal; ağlayan kadın için duygusal, itici, narin; erkek gibi oturan kadın için itici, erkeksi, anormal; erkek gibi yürüyen kadın için erkeksi, itici, anormal; el kol hareketleri erkek gibi olan kadın için itici, erkeksi, kaba.

Erkek iletişim kaynağının beden diline ilişkin en yüksek frekansı alan kalıpyargılar ise sırasıyla şöyledir: konuşurken yüksek sesle kahkaha atan erkek için itici, kendini beğenmiş, kaba; konuşurken sessizce gülümseyen kadın için kibar, çekici, normal; konuşurken yakın duran kadın için samimi, itici, anormal; konuşurken uzak duran erkek için normal, içe dönük, çekingen; konuşurken karşısındakine dokunan kadın için samimi, itici, anormal; konuşurken göz teması kuran erkek için samimi, normal, iddialı; konuşurken göz teması kurmayan erkek için kendine güvensiz, çekingen, içe dönük; somurtan erkek için itici, sıkıcı, kaba; ağlayan erkek için duygusal, itici, sıkıcı; kadın gibi oturan erkek için kadınsı, itici, anormal; kadın gibi yürüyen erkek için kadınsı, itici, anormal; el kol hareketleri kadın gibi olan erkek için kadınsı, itici, anormal.

\subsection{Evren ve Örneklem}

Kişilerarası iletişim sürecinde iletişim kaynağının toplumsal cinsiyet kimliğine ilişkin kalıpyargıların, kaynağın beden dili özellikleri üzerinden belirlenebilmesi ve belirlenen bu kalıpyargıların Türkiye’ye özgü bir perspektif sunabilmesi açısından, araştırmanın evreni Türkiye Cumhuriyeti vatandaşları olarak belirlenmiștir. Bu evren üzerinden ise, 18 yaş ve üzerindeki bireyler arasından evreni temsil edebilme gücü olan bir örnekleme ulaşmak hedeflenmiştir.

Bu kapsamda gerçekleştirilen araştırmanın örneklemi, basit tesadüfi örnekleme yoluyla ulaşılan bireyleri kapsamaktadır. Basit tesadüfi örneklemede evreni oluşturan her elemanın örneğe girme şansı eșittir. Dolayısıyla hesaplamalarda da her elemana verilen ağırlık da aynı olmaktadır (Arıkan, 2004, 141). Bu örneklemin kullanılabilmesi için ise, ele alınan problemlerle ilgili bilgilerin evrene göre homojen olması gerekmektedir (İslamoğlu, 2003, 47). Bu bağlamda düşünüldüğünde, 
kişilerarası iletişim sürecinde iletişim kaynağının, çeşitli beden dili özelliklerine bağlı olarak, toplumsal cinsiyetine yönelik kalıpyargıların belirlenmesinin hedeflendiği bu araștırmada, her bir birey üzerinden ulaşılacak verinin evrene göre homojen olduğunu söylemek yanlış olmayacaktır. Çünkü toplumsal yapı içerisinde bulunan her bir birey toplumsal cinsiyet rolüne ilişkin kalıpyargıları öğrenmekte ve tüm diğer süreçlerde olduğu gibi kişilerarası iletişim sürecinde de bu kalıpyargılarla karşılaşmaktadır. Bu bakımdan araştırma kapsamında basit tesadüfi örnekleme türünden yararlanılması uygun görülmüștür.

Söz konusu örnekleme dahil edilecek bireylerin seçiminde ise, Türkiye'nin farklı bölgelerinde yaşayan bireylere ulaşmak geniş bir bütçe ve zaman gerektiğinden, araştırmanın nüfusunu Türkiye'nin farklı bölgelerinden farklı özelliklere sahip bireylerin oluşturduğu İstanbul, İzmir ve Ankara olmak üzere ülkenin üç büyük şehrinde gerçekleștirilmesi yeterli görülmüştür.

Araştırma içerisinde örneklem büyüklügüne ilişkin bir hatayla karşılaşmamak adına ise, ulaşılan katılımcıların Türkiye'nin nüfusunu temsil eder bir düzeyde olmasına dikkat edilmiştir. Buna göre, Türkiye nüfusu göz önünde bulundurulduğunda ${ }^{1}$ çalışmada, 506 katılımcıyla ulaşılan örneklemin temsil düzeyi, \%95 güvenilirlik düzeyinde $\% 4,36$ 'lık hata payına, $\% 98$ güvenilirlik düzeyinde ise $\% 5,17^{\prime} l ı k$ hata payına tekabül etmektedir.

\subsection{Soru Formunun Hazırlanması, Uygulanması ve Verilerin Değerlendirilmesi}

Pilot araştırma aracılığıyla elde edilen verilerden yola çıkılarak hazırlanan soru formu içerisinde öncelikle araştırmanın örneklem grubunu oluşturan bireylerin demografik özelliklerini (cinsiyet, yaş, medeni hal, eğitim durumu, ikamet edilen il) belirlemeye yönelik sorulara yer verilmiștir. Bireyin beden diline ilișkin özellikler için ise, pilot araştırmada yer alan ifadeler ve her bir ifade için en yüksek frekansı alan ilk üç sıfat soru formuna dahil edilmiştir². Böylelikle katılımcıların soru formundaki uyarıcıları, sadece araştırmacı tarafından sunulan sözcüklerle değerlendirme yapmaya zorlanmasından kaçınılması hedeflenmiștir. Ayrıca soru formunda katılımcıya her uyarıcı için verilen ilk üç sıfatın birbirinden farklı olması, katılımcıya değerlendirdiği her uyarıcı için farklı sıfat seçenekleri sunmaktadır.

$\mathrm{Bu}$ bağlamda, anket formunda yer verilen soru biçiminde katılımclara belirli bir uyarıcı sunulmuş ve altında yer alan üç kalıpyargılı ifadeyi kendileri için en uygun olandan olmayana doğru sıralandırmaları (1: çok katılıyorum, 2: katılıyorum, 3: az katılıyorum) istenmiştir. Ayrıca katılımcılara, sıralandırmaya dahil etmek istemedikleri yani katılmadıkları sıfatları işaretlemelerine gerek olmadığı da aktarılmıştır. Bununla birlikte, anket formunun yanıtlanması sürecinde katılımcılara, projektif testlerdeki tamamlama yöntemine uygun olarak, çalışmanın temel amacı hakkında açıkça bilgi verilmemiş, söz konusu test içerisinde yapılan eşleștirmelerin bir doğrusunun ya da yanlışının bulunmadığı hatırlatılmıştır. Anket formu öncelikle çevrimiçi olarak 50 katılımcıya uygulanmış, bu süreçte bir sorunla karşılaşılmamıştır. Böylelikle anket formunun uygulanmasına karar verilmiş ve çevrimiçi olarak uygulanan form, Türkiye’nin üç büyük ilinde (İstanbul, İzmir, Ankara) 506 katılımcı tarafından cevaplandırılmıștır.

Araştırmanın değerlendirilebilmesi için, cevaplandırılan anket formlarına kodlama işlemi uygulanmış ve işlenmeye hazır hale getirilen veriler SPSS 22.0 programı 
kullanılarak bilgisayar ortamına aktarılmıştır. Verilerin analiz edilmesi aşamasında öncelikli olarak frekans analizlerine başvurulmuş yüzde tabloları elde edilmiştir. Sonrasında ise, araştırma sonuçlarının karşılaştırmalı tablolarına yer verilerek elde edilen bulgular yorumlanmıştır.

\section{Bulgular}

Araştırma bulguları çerçevesinde, öncelikle katılımcıların demografik özelliklerine yer verilmiş, sonrasında ise, iletişim kaynağının çeşitli beden dili özelliklerine bağlı olarak, toplumsal cinsiyet kimliği kalıpyargılarına, kalıpyargıların duygu durumlarına ve kalıpyargıların değerlendirenin cinsiyetiyle ilişkisine yönelik bulgular aktarılmıştır.

\subsection{Katılımcıların Demografik Özellikleri}

Araştırmada yer alan 506 katılımcının \%50,2'si (254 kişi) kadın, \%49,8'i (252 kişi) erkektir. Katılımcıların \%17,8'i (90 kişi) 18-24, \%2,1'i (132 kişi) 25-34, \%23,7'si (120 kişi) 35-44, \%18,6'sı (94 kişi) 45-54 ve \%13,8'i (70 kişi) 55-64 yaş aralığındadır. Katılımcıların, \%50,6'sı (256 kişi) evli, \%49,4'ü (250 kişi) bekardır. Katılımcıların \%10,9’u (55 kişi) ilkokul, \%17'si (86 kişi) ortaokul, \%43,1'i (218 kişi) lise, \%6,7’si (34 kişi) ön lisans, \%21,1'i (107 kişi) üniversite, \%1'i (5 kişi) yüksek lisans, \%0,2'si (1 kişi) ise doktora programı mezunudur. Katılımcıların yaşadıkları șehir dağılımına bakıldığında ise, katılımcıların \%19,8'inin (100 kiși) Ankara, \%60,3'ü (305 kişi) İstanbul, \%20’si (101 kişi) ise İzmir'de ikamet ettiği görülmektedir.

\subsection{Kadın ve Erkek İletişim Kaynağının Beden Diline İliş̧kin Kalıpyargılar}

Kişilerarası iletişim sürecinde kadın ve erkek iletişim kaynağının beden diline ilişkin bulgulanan kalıpyargıları karşılaştırmalı olarak gösteren frekans tablosu aşağıda yer almaktadır.

Tablo 1: Kadın ve erkek iletişim kaynağının beden dili hakkındaki kalıpyargıların frekans analizi tablosu.

\begin{tabular}{|c|c|c|c|c|c|c|c|}
\hline & \multicolumn{3}{|c|}{ Konuşurken yüksek sesle kahkaha atan bir kadın } & & \multicolumn{3}{|c|}{ Konuşurken yüksek sesle kahkaha atan bir erkek } \\
\hline & $\begin{array}{l}\text { İtici } \\
(-)\end{array}$ & $\begin{array}{l}\text { Dışa dönük } \\
(+)\end{array}$ & $\begin{array}{l}\text { Kendini } \\
\text { beğenmiş } \\
(-)\end{array}$ & & $\begin{array}{l}\text { İtici } \\
(-)\end{array}$ & $\begin{array}{l}\text { Kendini } \\
\text { beğenmiş } \\
(-)\end{array}$ & $\begin{array}{l}\text { Kaba } \\
(-)\end{array}$ \\
\hline 1 & \begin{tabular}{|l} 
\%33,6 \\
(170 kişi)
\end{tabular} & $\begin{array}{l}\text { \%51,4 } \\
\text { (260 kişi) }\end{array}$ & $\begin{array}{l}\text { \%15 } \\
\text { (76 kişi) }\end{array}$ & 1 & $\begin{array}{l}\text { \%32,8 } \\
\text { (166 kişi) }\end{array}$ & $\begin{array}{l}\text { \%40,7 } \\
\text { (206 kişi) }\end{array}$ & $\begin{array}{l}\text { \%26,5 } \\
\text { (134 kişi) }\end{array}$ \\
\hline 2 & \begin{tabular}{|l} 
\%29,1 \\
(147 kişi)
\end{tabular} & $\begin{array}{l}\text { \%28,1 } \\
\text { (142 kişi) }\end{array}$ & $\begin{array}{l}\text { \%42,9 } \\
\text { (217 kişi) }\end{array}$ & 2 & $\begin{array}{l}\text { \%33,8 } \\
\text { (171 kişi) }\end{array}$ & \begin{tabular}{|l} 
\%26,9 \\
(136 kişi)
\end{tabular} & $\begin{array}{l}\text { \%39,3 } \\
\text { (199 kişi) }\end{array}$ \\
\hline \multirow[t]{3}{*}{3} & \begin{tabular}{|l} 
\%37,4 \\
(189 kişi)
\end{tabular} & $\begin{array}{l}\text { \%20,6 } \\
\text { (104 kişi) }\end{array}$ & $\begin{array}{l}\text { \%42,1 } \\
(213 \text { kişi) }\end{array}$ & 3 & $\begin{array}{l}\text { \%33,4 } \\
\text { (169 kişi) }\end{array}$ & \begin{tabular}{|l} 
\%32,4 \\
(164 kişi)
\end{tabular} & $\begin{array}{l}\text { \%34,2 } \\
\text { (173 kişi) }\end{array}$ \\
\hline & \multicolumn{3}{|c|}{ Konuşurken sessizce gülümseyen bir kadın } & & \multicolumn{3}{|c|}{ Konuşurken sessizce gülümseyen bir erkek } \\
\hline & $\begin{array}{l}\text { Kibar } \\
(+)\end{array}$ & $\begin{array}{l}\text { Normal } \\
(+)\end{array}$ & $\begin{array}{l}\text { Çekici } \\
(+)\end{array}$ & & $\begin{array}{l}\text { Kibar } \\
(+)\end{array}$ & $\begin{array}{l}\text { Çekici } \\
(+)\end{array}$ & $\begin{array}{l}\text { Normal } \\
(+)\end{array}$ \\
\hline 1 & \begin{tabular}{|l} 
\%38,7 \\
(196 kişi)
\end{tabular} & $\begin{array}{l}\text { \% 45,3 } \\
\text { (229 kişi) }\end{array}$ & $\begin{array}{l}\text { \%16 } \\
\text { (81 kişi) }\end{array}$ & 1 & $\begin{array}{l}\% 41,3 \\
\text { (209 kişi) }\end{array}$ & $\begin{array}{l}\text { \%31,6 } \\
(160 \text { kişi) }\end{array}$ & $\begin{array}{l}\% 27,1 \\
(137 \text { kişi) }\end{array}$ \\
\hline 2 & $\begin{array}{l}\text { \%39,3 } \\
\text { (199 kişi) }\end{array}$ & $\begin{array}{l}\% 28,9 \\
\text { (146 kişi) }\end{array}$ & $\begin{array}{l}\text { \%31,8 } \\
\text { (161 kişi) }\end{array}$ & 2 & $\begin{array}{l}\text { \% 40,3 } \\
\text { (204 kişi) }\end{array}$ & $\begin{array}{l}\text { \%33 } \\
\text { (167 kişi) }\end{array}$ & $\begin{array}{l}\text { \%26,7 } \\
\text { (135 kişi) }\end{array}$ \\
\hline 3 & $\begin{array}{l}\text { \%21,9 } \\
\text { (111 kişi) }\end{array}$ & $\begin{array}{l}\text { \%25,9 } \\
\text { (131 kişi) }\end{array}$ & $\begin{array}{l}\text { \%52,2 } \\
\text { (264 kişi) }\end{array}$ & 3 & $\begin{array}{l}\text { \%18,4 } \\
\text { (93 kişi) }\end{array}$ & $\begin{array}{l}\text { \%35,4 } \\
\text { (179 kişi) }\end{array}$ & $\begin{array}{l}\text { \%46,2 } \\
\text { (234 kişi) }\end{array}$ \\
\hline
\end{tabular}




\begin{tabular}{|c|c|c|c|c|c|c|c|}
\hline & \multicolumn{3}{|c|}{ Konuşurken yakın duran bir kadın } & & \multicolumn{3}{|c|}{ Konuşurken yakın duran bir erkek } \\
\hline & \begin{tabular}{|l}
$\begin{array}{l}\text { Samimi } \\
(+)\end{array}$ \\
\end{tabular} & \begin{tabular}{|l} 
itici \\
$(-)$ \\
\end{tabular} & \begin{tabular}{|l|}
$\begin{array}{l}\text { Normal } \\
(+)\end{array}$ \\
\end{tabular} & & \begin{tabular}{|l}
$\begin{array}{l}\text { Samimi } \\
(+)\end{array}$ \\
\end{tabular} & \begin{tabular}{|l} 
Itici \\
$(-)$
\end{tabular} & \begin{tabular}{|l|}
$\begin{array}{l}\text { Anormal } \\
(-)\end{array}$ \\
\end{tabular} \\
\hline 1 & $\begin{array}{l}\text { \%51,8 } \\
(262 \text { kişi) }\end{array}$ & \begin{tabular}{|l|}
$\% 22,7$ \\
$(115$ kişi) \\
\end{tabular} & $\begin{array}{l}\% 25,5 \\
\text { (129 kişi) }\end{array}$ & 1 & \begin{tabular}{|l}
$\% 41,9$ \\
(212 kişi) \\
\end{tabular} & $\begin{array}{l}\text { \%34 } \\
\text { (172 kişi) } \\
\end{array}$ & \begin{tabular}{|l|}
$\% 23,3$ \\
(118 kişi)
\end{tabular} \\
\hline 2 & \begin{tabular}{|l|}
$\% 34,4$ \\
$(174$ kişi) \\
\end{tabular} & \begin{tabular}{|l|}
$\% 19,4$ \\
(98 kişi)
\end{tabular} & \begin{tabular}{|l} 
\%46,2 \\
(234 kişi)
\end{tabular} & 2 & \begin{tabular}{|l} 
\%20,6 \\
(104 kişi)
\end{tabular} & \begin{tabular}{|l}
$\% 35,6$ \\
(180 kişi) \\
\end{tabular} & \begin{tabular}{|l} 
\%43,1 \\
(218 kişi)
\end{tabular} \\
\hline \multirow[t]{3}{*}{3} & \begin{tabular}{|l|}
$\% 13,8$ \\
$(70$ kişi)
\end{tabular} & $\begin{array}{l}\% 57,9 \\
(293 \text { kişi) } \\
\end{array}$ & $\begin{array}{l}\text { \%28,3 } \\
\text { (143 kişi) } \\
\end{array}$ & 3 & \begin{tabular}{|l} 
\%36,8 \\
(186 kişi)
\end{tabular} & \begin{tabular}{|l}
$\% 29,6$ \\
$(150$ kişi) \\
\end{tabular} & \begin{tabular}{|l|}
$\% 32,8$ \\
(166 kişi) \\
\end{tabular} \\
\hline & \multicolumn{3}{|c|}{ Konuşurken uzak duran bir kadın } & & \multicolumn{3}{|c|}{ Konuşurken uzak duran bir erkek } \\
\hline & $\begin{array}{l}\text { Çekingen } \\
(-)\end{array}$ & \begin{tabular}{|l|} 
İçe dönük \\
$(-)$
\end{tabular} & \begin{tabular}{|l|}
$\begin{array}{l}\text { Normal } \\
(+)\end{array}$ \\
\end{tabular} & & \begin{tabular}{|l|}
$\begin{array}{l}\text { Normal } \\
(+)\end{array}$ \\
\end{tabular} & $\begin{array}{l}\text { liçe dönük } \\
(-)\end{array}$ & $\begin{array}{l}\text { Çekingen } \\
(-)\end{array}$ \\
\hline 1 & $\begin{array}{l}\text { \%37,4 } \\
\text { (189 kişi) }\end{array}$ & \begin{tabular}{|l|}
$\% 36,8$ \\
(186 kişi)
\end{tabular} & $\begin{array}{l}\% 25,9 \\
\text { (131 kişi) }\end{array}$ & 1 & $\begin{array}{l}\text { \% 40,9 } \\
(207 \text { kişi) }\end{array}$ & $\begin{array}{l}\text { \%38,3 } \\
\text { (194 kişi) }\end{array}$ & $\begin{array}{l}\% 20,8 \\
\text { (105 kişi) }\end{array}$ \\
\hline 2 & $\begin{array}{l}\text { \%46 } \\
\text { (233 kişi) }\end{array}$ & \begin{tabular}{|l|} 
\%37 \\
(187 kişi)
\end{tabular} & \begin{tabular}{|l|}
$\% 17$ \\
(86 kişi)
\end{tabular} & 2 & $\begin{array}{l}\% 25,5 \\
\text { (129 kişi) }\end{array}$ & $\begin{array}{l}\text { \%32 } \\
\text { (162 kişi) }\end{array}$ & $\begin{array}{l}\text { \%42,5 } \\
\text { (215 kişi) }\end{array}$ \\
\hline \multirow[t]{3}{*}{3} & \begin{tabular}{|l|}
$\% 16,6$ \\
(84 kişi)
\end{tabular} & \begin{tabular}{|l|}
$\% 26,3$ \\
(133 kişi)
\end{tabular} & \begin{tabular}{|l}
$\% 57,1$ \\
(289 kişi)
\end{tabular} & 3 & $\begin{array}{l}\text { \%33,6 } \\
\text { (170 kişi) }\end{array}$ & $\begin{array}{l}\text { \%29,6 } \\
\text { (150 kişi) }\end{array}$ & $\begin{array}{l}\% 36,8 \\
\text { (186 kişi) }\end{array}$ \\
\hline & \multicolumn{3}{|c|}{ Konuşurken karşısındakine dokunan bir kadın } & & \multicolumn{3}{|c|}{ Konuşurken karşısındakine dokunan bir erkek } \\
\hline & \begin{tabular}{|l} 
Samimi \\
$(+)$
\end{tabular} & \begin{tabular}{|l} 
itici \\
$(-)$ \\
\end{tabular} & \begin{tabular}{|l}
$\begin{array}{l}\text { Dişa dönük } \\
(+)\end{array}$ \\
\end{tabular} & & \begin{tabular}{|l}
$\begin{array}{l}\text { Samimi } \\
(+)\end{array}$ \\
\end{tabular} & \begin{tabular}{|l} 
itici \\
$(-)$
\end{tabular} & \begin{tabular}{|l|}
$\begin{array}{l}\text { Anormal } \\
(-)\end{array}$ \\
\end{tabular} \\
\hline 1 & $\begin{array}{l}44,5 \\
(225 \text { kişi) }\end{array}$ & $\begin{array}{l}\text { \%31,6 } \\
\text { (160 kişi) }\end{array}$ & $\begin{array}{l}\% 23,9 \\
\text { (121 kişi) }\end{array}$ & 1 & $\begin{array}{l}\% 28,9 \\
\text { (146 kişi) }\end{array}$ & $\begin{array}{l}\text { \%46,4 } \\
\text { (235 kişi) }\end{array}$ & $\begin{array}{l}\text { \%24,7 } \\
\text { (125 kişi) }\end{array}$ \\
\hline 2 & \begin{tabular}{|l|}
$\% 26,3$ \\
(133 kişi)
\end{tabular} & \begin{tabular}{|l|}
$\% 21,9$ \\
(111 kişi)
\end{tabular} & \begin{tabular}{|l}
$\% 51,8$ \\
(262 kişi)
\end{tabular} & 2 & \begin{tabular}{|l} 
\%22,1 \\
(112 kişi)
\end{tabular} & \begin{tabular}{|l} 
\%30,2 \\
(153 kişi)
\end{tabular} & \begin{tabular}{|l}
$\% 47,6$ \\
$(241$ kişi)
\end{tabular} \\
\hline \multirow[t]{3}{*}{3} & $\begin{array}{l}\% 29,2 \\
\text { (148 kişi) }\end{array}$ & $\begin{array}{l}\% 46,4 \\
(235 \text { kişi) }\end{array}$ & $\begin{array}{l}\% 24,3 \\
\text { (123 kişi) }\end{array}$ & 3 & $\begin{array}{l}\text { \%49 } \\
\text { (248 kişi) }\end{array}$ & $\begin{array}{l}\text { \%23,3 } \\
\text { (118 kişi) }\end{array}$ & \begin{tabular}{|l}
$\% 27,7$ \\
(140 kişi)
\end{tabular} \\
\hline & \multicolumn{3}{|c|}{ Somurtan bir kadın } & & \multicolumn{3}{|c|}{ Somurtan bir erkek } \\
\hline & Sıkıcı & itici & Normal & & ítici & Sıkıcı & Kaba \\
\hline 1 & $\begin{array}{l}\% 47,4 \\
(240 \text { kişi) }\end{array}$ & \begin{tabular}{|l|} 
\%34 \\
(172 kişi)
\end{tabular} & \begin{tabular}{|l|}
$\% 18,2$ \\
(92 kişi)
\end{tabular} & 1 & $\begin{array}{l}\text { \%31,8 } \\
\text { (161 kişi) }\end{array}$ & $\begin{array}{l}\text { \%50,6 } \\
\text { (256 kişi) }\end{array}$ & \begin{tabular}{|l|}
$\% 17,4$ \\
$(88$ kişi)
\end{tabular} \\
\hline 2 & $\begin{array}{l}443,5 \\
(220 \text { kişi) }\end{array}$ & \begin{tabular}{|l|}
$\% 42,5$ \\
$(215$ kişi) \\
\end{tabular} & \begin{tabular}{|l|}
$\% 13,6$ \\
(69 kişi)
\end{tabular} & 2 & $\begin{array}{l}\text { \% 40,3 } \\
\text { (204 kişi) }\end{array}$ & $\begin{array}{l}\text { \%26,5 } \\
\text { (134 kişi) }\end{array}$ & \begin{tabular}{|l|} 
\%33 \\
(167 kişi)
\end{tabular} \\
\hline \multirow[t]{3}{*}{3} & \begin{tabular}{|l}
88,7 \\
$(44$ kişi)
\end{tabular} & $\begin{array}{l}\% 23,1 \\
(117 \text { kişi) } \\
\end{array}$ & $\begin{array}{l}\text { \%67,8 } \\
\text { (343 kişi) }\end{array}$ & 3 & \begin{tabular}{|l} 
\%27,7 \\
(140 kişi)
\end{tabular} & \begin{tabular}{|l} 
\%22,7 \\
(115 kişi)
\end{tabular} & \begin{tabular}{|l}
$\% 49,4$ \\
$(250$ kişi)
\end{tabular} \\
\hline & \multicolumn{3}{|c|}{ Ağlayan bir kadın } & & \multicolumn{3}{|c|}{ Ağlayan bir erkek } \\
\hline & $\begin{array}{l}\text { Duygusal } \\
(-)\end{array}$ & \begin{tabular}{|l} 
itici \\
$(-)$
\end{tabular} & \begin{tabular}{|l} 
Narin \\
$(-)$
\end{tabular} & & $\begin{array}{l}\text { Duygusal } \\
(-)\end{array}$ & \begin{tabular}{|l} 
Itici \\
$(-)$
\end{tabular} & $\begin{array}{l}\text { SıkıCı } \\
(-)\end{array}$ \\
\hline 1 & \begin{tabular}{|l|}
$\% 62,1$ \\
(314 kişi)
\end{tabular} & $\begin{array}{l}\% 13,4 \\
\text { (68 kişi) }\end{array}$ & \begin{tabular}{|l|}
$\% 24,5$ \\
(124 kişi)
\end{tabular} & 1 & $\begin{array}{l}\text { \%49,6 } \\
\text { (251 kişi) }\end{array}$ & $\begin{array}{l}\text { \%33,2 } \\
\text { (168 kişi) }\end{array}$ & \begin{tabular}{|l|}
$\% 17,2$ \\
$(87$ kişi)
\end{tabular} \\
\hline 2 & \begin{tabular}{|l|}
$\% 27,5$ \\
(139 kişi)
\end{tabular} & \begin{tabular}{|l|}
$\% 14,8$ \\
$(75$ kişi)
\end{tabular} & \begin{tabular}{|l}
$\% 57,7$ \\
$(292$ kişi)
\end{tabular} & 2 & \begin{tabular}{|l|}
$\% 19,4$ \\
(98 kişi)
\end{tabular} & \begin{tabular}{|l} 
\%25,3 \\
(128 kişi)
\end{tabular} & $\begin{array}{l}\text { \%55,3 } \\
\text { (280 kişi) }\end{array}$ \\
\hline \multirow[t]{3}{*}{3} & \begin{tabular}{|l|}
$\% 10,5$ \\
(53 kişi)
\end{tabular} & $\begin{array}{l}\text { \%71,7 } \\
\text { (363 kişi) } \\
\end{array}$ & $\begin{array}{l}\text { \%17,8 } \\
\text { (90 kişi) }\end{array}$ & 3 & \begin{tabular}{|l|} 
\%31 \\
(157 kişi)
\end{tabular} & $\begin{array}{l}\text { \%41,5 } \\
\text { (210 kişi) }\end{array}$ & $\begin{array}{l}\text { \%27,5 } \\
\text { (139 kişi) }\end{array}$ \\
\hline & \multicolumn{3}{|c|}{ Erkek gibi oturan bir kadın } & & \multicolumn{3}{|c|}{ Kadın gibi oturan bir erkek } \\
\hline & \begin{tabular}{|l} 
İtici \\
$(-)$
\end{tabular} & \begin{tabular}{|l} 
Erkeksi \\
(Nötr)
\end{tabular} & \begin{tabular}{|l} 
Anormal \\
$(-)$
\end{tabular} & & \begin{tabular}{|l|} 
Kadınsı \\
(Nötr)
\end{tabular} & \begin{tabular}{|l} 
İtici \\
$(-)$
\end{tabular} & \begin{tabular}{|l} 
Anormal \\
$(-)$
\end{tabular} \\
\hline 1 & $\begin{array}{l}\text { \%32 } \\
\text { (162 kişi) }\end{array}$ & $\begin{array}{l}\% 46 \\
\text { (233 kişi) }\end{array}$ & $\begin{array}{l}\% 21,9 \\
\text { (111 kişi) }\end{array}$ & 1 & $\begin{array}{l}\text { \%33,8 } \\
\text { (171 kişi) }\end{array}$ & $\begin{array}{l}\text { \%32,8 } \\
\text { (166 kişi) }\end{array}$ & $\begin{array}{l}\text { \%33,4 } \\
\text { (169 kişi) }\end{array}$ \\
\hline 2 & $\begin{array}{l}\% 36,2 \\
\text { (183 kişi) }\end{array}$ & $\begin{array}{l}\% 25,9 \\
\text { (131 kişi) }\end{array}$ & $\begin{array}{l}\text { \%37,9 } \\
\text { (192 kişi) }\end{array}$ & 2 & $\begin{array}{l}\text { \%28,7 } \\
\text { (145 kişi) }\end{array}$ & $\begin{array}{l}\text { \%35,8 } \\
\text { (181 kişi) }\end{array}$ & $\begin{array}{l}\text { \%35,6 } \\
\text { (180 kişi) }\end{array}$ \\
\hline 3 & $\begin{array}{l}\text { \%31,8 } \\
\text { (161 kişi) }\end{array}$ & $\begin{array}{l}\% 28,1 \\
\text { (142 kişi) }\end{array}$ & $\begin{array}{l}\% \text { 40,1 } \\
\text { (203 kişi) }\end{array}$ & 3 & $\begin{array}{l}\% 37,5 \\
\text { (190 kişi) }\end{array}$ & $\begin{array}{l}\text { \%31,4 } \\
\text { (159 kişi) }\end{array}$ & $\begin{array}{l}\text { \%31 } \\
\text { (157 kişi) }\end{array}$ \\
\hline
\end{tabular}




\begin{tabular}{|c|c|c|c|c|c|c|c|}
\hline & \multicolumn{3}{|c|}{ Erkek gibi yürüyen bir kadın } & & \multicolumn{3}{|c|}{ Kadın gibi yürüyen bir erkek } \\
\hline & $\begin{array}{l}\text { Erkeksi } \\
\text { (Nötr) }\end{array}$ & \begin{tabular}{|l} 
Itici \\
$(-)$
\end{tabular} & \begin{tabular}{|l|} 
Anormal \\
$(-)$
\end{tabular} & & \begin{tabular}{|l|} 
Kadınsı \\
(Nötr)
\end{tabular} & \begin{tabular}{|l} 
İtici \\
$(-)$
\end{tabular} & \begin{tabular}{|l|} 
Anormal \\
$(-)$
\end{tabular} \\
\hline 1 & $\begin{array}{l}\text { \%43,5 } \\
(220 \text { kişi) }\end{array}$ & $\begin{array}{l}\% 30,8 \\
\text { (156 kişi) }\end{array}$ & \begin{tabular}{|l|}
$\% 25,7$ \\
$(130$ kişi)
\end{tabular} & 1 & $\begin{array}{l}\% 28,9 \\
\text { (146 kişi) }\end{array}$ & $\begin{array}{l}\% 34,8 \\
\text { (176 kişi) }\end{array}$ & $\begin{array}{l}\text { \%36,4 } \\
(184 \text { kişi) }\end{array}$ \\
\hline 2 & $\begin{array}{l}\text { \%27,5 } \\
\text { (139 kişi) }\end{array}$ & \begin{tabular}{|l} 
\%34,8 \\
(176 kişi)
\end{tabular} & \begin{tabular}{|l}
$\% 37,7$ \\
$(191$ kişi)
\end{tabular} & 2 & $\begin{array}{l}\% 25,3 \\
\text { (128 kişi) }\end{array}$ & $\begin{array}{l}\text { \%37,7 } \\
\text { (191 kişi) }\end{array}$ & $\begin{array}{l}\% 37 \\
\text { (187 kişi) }\end{array}$ \\
\hline \multirow[t]{3}{*}{3} & $\begin{array}{l}\text { \%29,1 } \\
\text { (147 kişi) }\end{array}$ & \begin{tabular}{|l|l} 
\%34,4 \\
(174 kişi)
\end{tabular} & \begin{tabular}{|l}
$\% 36,6$ \\
$(185$ kişi)
\end{tabular} & 3 & $\begin{array}{l}\text { \%45,8 } \\
\text { (232 kişi) }\end{array}$ & $\begin{array}{l}\% 27,5 \\
(139 \text { kişi) }\end{array}$ & \begin{tabular}{|l|}
$\% 26,7$ \\
(135 kişi)
\end{tabular} \\
\hline & \multicolumn{3}{|c|}{ El kol hareketleri erkek gibi olan bir kadın } & & \multicolumn{3}{|c|}{ El kol hareketleri kadın gibi olan bir erkek } \\
\hline & $\begin{array}{l}\text { İtici } \\
(-)\end{array}$ & \begin{tabular}{|l} 
Erkeksi \\
(Nötr)
\end{tabular} & \begin{tabular}{|l} 
Kaba \\
$(-)$
\end{tabular} & & \begin{tabular}{|l|} 
Kadınsı \\
(Nötr)
\end{tabular} & \begin{tabular}{|l} 
İtici \\
$(-)$
\end{tabular} & \begin{tabular}{|l|} 
Anormal \\
$(-)$
\end{tabular} \\
\hline 1 & $\begin{array}{l}\text { \%33,4 } \\
\text { (169 kişi) }\end{array}$ & \begin{tabular}{|l}
$\% 41,5$ \\
$(210$ kişi)
\end{tabular} & $\begin{array}{l}\% 25,1 \\
\text { (127 kişi) }\end{array}$ & 1 & $\begin{array}{l}\% 29,1 \\
\text { (147 kişi) }\end{array}$ & $\begin{array}{l}\text { \%37,9 } \\
\text { (192 kişi) }\end{array}$ & $\begin{array}{l}\% 33 \\
\text { (167 kişi) }\end{array}$ \\
\hline 2 & $\begin{array}{l}\text { \%33,4 } \\
\text { (169 kişi) }\end{array}$ & $\begin{array}{l}\% 26,3 \\
\text { (133 kişi) }\end{array}$ & $\begin{array}{l}40,3 \\
\text { (204 kişi) }\end{array}$ & 2 & $\begin{array}{l}\% 22,5 \\
\text { (114 kişi) }\end{array}$ & \begin{tabular}{|l}
$\% 38,1$ \\
(193 kişi)
\end{tabular} & $\begin{array}{l}\text { \%39,3 } \\
\text { (199 kişi) }\end{array}$ \\
\hline 3 & $\begin{array}{l}\text { \%33,2 } \\
\text { (168 kişi) }\end{array}$ & $\begin{array}{l}\% 32,2 \\
\text { (163 kişi) }\end{array}$ & $\begin{array}{l}\% 34,6 \\
\text { (175 kişi) }\end{array}$ & 3 & $\begin{array}{l}\text { \%48,4 } \\
\text { (245 kişi) }\end{array}$ & $\begin{array}{l}\text { \%23,9 } \\
\text { (121 kişi) }\end{array}$ & $\begin{array}{l}\% 27,7 \\
(140 \text { kişi) }\end{array}$ \\
\hline
\end{tabular}

Tabloya göre, kadın iletişim kaynağının beden diline ilișkin bulgulanan kalıpyargılar sırasıyla şöyledir: yüksek sesle kahkaha atan kadın için dışa dönük, kendini beğenmiş; sessizce gülümseyen kadın için normal, kibar, çekici; yakın duran kadın için samimi, normal, itici; uzak duran kadın için çekingen, normal; konuşurken karşısındakine dokunan kadın için samimi, dışa dönük, itici; somurtan kadın için sıkıcı, normal; ağlayan kadın için duygusal, narin, itici; erkek gibi oturan için erkeksi, anormal; erkek gibi yürüyen kadın için erkeksi, anormal; el kol hareketleri erkek gibi olan kadın için erkeksi, kaba.

Erkek iletişim kaynağının beden diline ilişkin bulgulanan kalıpyargılar ise sırasıyla şöyledir: yüksek sesle kahkaha atan erkek için kendini beğenmiş, kaba; sessizce gülümseyen erkek için kibar, normal; yakın duran erkek için samimi, anormal; uzak duran erkek için normal, çekingen; konuşurken karşısındakine dokunan erkek için itici, anormal, samimi; somurtan erkek için sıkıcı, itici, kaba; ağlayan erkek için duygusal, sıkıcı, itici; kadın gibi oturan erkek için kadınsı, itici; kadın gibi yürüyen erkek için anormal, itici, kadınsı; el kol hareketleri kadın gibi olan erkek için itici, anormal, kadinsı.

Dolayısıyla kadın ve erkek iletişim kaynağının konuşma ve dinleme biçimlerine ilişkin kalıpyargıların farklılaştığını söylemek mümkündür. Bununla birlikte, bazı uyarıcılara ilişkin en yüksek frekansı alan kalıpyargıların (konuşurken yakın duran kadın ve erkek, somurtan kadın ve erkek, ağlayan kadın ve erkek, kadın/erkek gibi oturan kadın/erkek) aynı olduğu görülmektedir. Bu durumu belirli uyarıcılara ilişkin kalıpyargıların cinsiyet fark etmeksizin aynılaşması biçiminde açıklamak mümkündür. Ancak uyarıcılara yönelik sonrasındaki kalıpyargılar toplumsal cinsiyet kimliğine bağlı olarak farklılık göstermiștir.

\section{3. İletişim Kaynağının Beden Dilline İlişkin Kalıpyargıların Değerlendirenin Toplumsal Cinsiyetiyle İlişkisi}

İletişim kaynağının beden dili hakkındaki kalıpyargılara ilişkin değerlendirenlerin toplumsal cinsiyeti arasında anlamlı bir ilişkinin bulunup bulunmadığının tespit edilebilmesi için bağımsız örneklem t-testi uygulanmıștır. Buna göre, kadın ve erkek iletişim kaynağının beden dili ve değerlendirenin cinsiyetin arasında anlamlı 
ilişki bulunduğu tespit edilen ifadelerin bağımsız örneklem t-testi sonuçları aşağıdaki gibidir:

Tablo 2: Illetişim kaynağının beden diline ilişskin kalıpyargıların değerlendirenin toplumsal cinsiyetiyle ilişkisi

\begin{tabular}{|c|c|c|c|c|c|c|}
\hline & Cinsiyet & N & Ortalama & $\begin{array}{c}\text { St. } \\
\text { Sapma }\end{array}$ & $\mathbf{t}$ & $\mathbf{P}$ \\
\hline \multirow{2}{*}{$\begin{array}{l}\text { Konuşurken sessizce gülümseyen } \\
\text { bir kadınla karşılaştığımda onun } \\
\text { çekici olduğunu düşünürüm. }\end{array}$} & Kadın & 254 & 2,45 & 0,741 & 2,665 & 0,008 \\
\hline & Erkek & 252 & 2,27 & 0,736 & 2,665 & 0,008 \\
\hline \multirow{2}{*}{$\begin{array}{l}\text { Erkek gibi oturan bir kadınla } \\
\text { karşılaştığımda onun erkeksi } \\
\text { olduğunu düşünürüm. }\end{array}$} & Kadın & 254 & 1,73 & 0,816 & $-2,473$ & 0,014 \\
\hline & Erkek & 252 & 1,91 & 0,861 & $-2,472$ & 0,014 \\
\hline \multirow{2}{*}{$\begin{array}{l}\text { Erkek gibi oturan bir kadınla } \\
\text { karşılaştığımda onun anormal } \\
\text { olduğunu düşünürüm. }\end{array}$} & Kadın & 254 & 2,28 & 0,751 & 2,778 & 0,006 \\
\hline & Erkek & 252 & 2,09 & 0,773 & 2,778 & 0,006 \\
\hline \multirow{2}{*}{$\begin{array}{l}\text { Erkek gibi yürüyen bir kadınla } \\
\text { karşılaştığımda onun anormal } \\
\text { olduğunu düşünürüm. }\end{array}$} & Kadın & 254 & 2,18 & 0,759 & 2,097 & 0,036 \\
\hline & Erkek & 252 & 2,04 & 0,800 & 2,097 & 0,036 \\
\hline \multirow{2}{*}{$\begin{array}{l}\text { Konuşurken sessizce gülümseyen } \\
\text { bir erkekle karşılaştığımda onun } \\
\text { çekici olduğunu düşünürüm. }\end{array}$} & Kadın & 254 & 1,89 & 0,796 & $-4,029$ & 0,000 \\
\hline & Erkek & 252 & 2,18 & 0,817 & $-4,029$ & 0,000 \\
\hline \multirow{2}{*}{$\begin{array}{l}\text { Konuşurken sessizce gülümseyen } \\
\text { bir erkekle karşılaştığımda onun } \\
\text { normal olduğunu düşünürüm. }\end{array}$} & Kadın & 254 & 2,29 & 0,806 & 2,711 & 0,007 \\
\hline & Erkek & 252 & 2,09 & 0,854 & 2,710 & 0,007 \\
\hline \multirow{2}{*}{$\begin{array}{l}\text { Konuşurken yakın duran bir } \\
\text { erkekle karşılaştığımda onun } \\
\text { itici olduğunu düşünürüm. }\end{array}$} & Kadın & 252 & 1,85 & 0,797 & $-2,916$ & 0,004 \\
\hline & Erkek & 250 & 2,06 & 0,792 & $-2,916$ & 0,004 \\
\hline \multirow{2}{*}{$\begin{array}{l}\text { Konuşurken yakın duran bir } \\
\text { erkekle karşılaştığımda onun } \\
\text { anormal olduğunu düşünürüm. }\end{array}$} & Kadın & 252 & 2,19 & 0,715 & 2,756 & 0,006 \\
\hline & Erkek & 250 & 2,00 & 0,768 & 2,755 & 0,006 \\
\hline \multirow{2}{*}{$\begin{array}{l}\text { Kadın gibi oturan bir erkekle } \\
\text { karşılaştığımda onun anormal } \\
\text { olduğunu düşünürüm. }\end{array}$} & Kadın & 254 & 2,06 & 0,775 & 2,338 & 0,020 \\
\hline & Erkek & 252 & 1,89 & 0,823 & 2,337 & 0,020 \\
\hline \multirow{2}{*}{$\begin{array}{l}\text { Kadın gibi yürüyen bir erkekle } \\
\text { karşılaştığımda onun anormal } \\
\text { olduğunu düşünürüm. }\end{array}$} & Kadın & 254 & 1,97 & 0,762 & 1,989 & 0,047 \\
\hline & Erkek & 252 & 1,83 & 0,811 & 1,989 & 0,047 \\
\hline \multirow{2}{*}{$\begin{array}{l}\text { El kol hareketleri kadın gibi olan } \\
\text { bir erkekle karşılaştığımda onun } \\
\text { anormal olduğunu düşünürüm. }\end{array}$} & Kadın & 254 & 2,04 & 0,729 & 2,826 & 0,005 \\
\hline & Erkek & 252 & 1,85 & 0,814 & 2,825 & 0,005 \\
\hline
\end{tabular}

Yukarıdaki tabloda yer alan ifadelerle ve cinsiyet arasında anlamlı bir ilişki olduğu görülmektedir. Bununla birlikte tablo üzerinden kadınların konuşurken sessizce gülümseyen bir kadının onun çekici olduğunu; erkeklerin erkek gibi oturan bir kadının erkeksi olduğunu; kadınların erkek gibi oturan bir kadının anormal olduğunu; kadınların erkek gibi yürüyen bir kadının anormal olduğunu; erkeklerin konuşurken sessizce gülümseyen bir erkeğin çekici olduğunu, kadınların sessizce gülümseyen bir erkeğin normal olduğunu; erkeklerin konuşurken yakın duran bir erkeğin itici olduğunu; kadınların konuşurken yakın duran bir erkeğin anormal olduğunu; kadınların kadın gibi oturan bir erkeğin anormal olduğunu; kadınların kadın gibi yürüyen bir erkeğin anormal olduğunu; kadınların el kol hareketleri kadın gibi olan bir erkeğin anormal olduğunu daha yüksek oranda düşündüklerini söylemek mümkündür. 


\section{Sonuç}

Bireyin toplumsal cinsiyet kimliğine bağlı olarak toplum içerisinde karşılaştığı kalıpyargılar, kişilerarası iletişim süreci için de büyük önem taşımakta, bireyler toplumsal cinsiyet kimlikleri nedeniyle karşılaștıkları kalıpyargılar dolayısıyla çeşitli iletişim engelleriyle karşılaşabilmektedirler. Bu bakımdan araştırma kapsamında kişilerarası iletişim sürecinde kadın ve erkek iletişim kaynağının çeşitli beden dili özellikleri hakkında, toplumsal cinsiyet kimliğine bağlı olarak ortaya çıkan kalıpyargılar incelenmiștir. Ayrıca söz konusu kalıpyargıların duygusal boyutu ve kalıpyargıların değerlendirenin cinsiyetine bağlı olarak nasıl bir farklılık gösterdiği de saptanmıştır.

Buna göre, kadın iletişim kaynağının beden diline yönelik kalıpyargılar ve bu kalıpyargılara ilişkin duygu durumları sırasıyla şöyle olmuştur: yüksek sesle kahkaha atan kadın için dışa dönük (+), kendini beğenmiş (-); sessizce gülümseyen kadın için normal (+), kibar (+), çekici (+); yakın duran kadın için samimi $(+)$, normal $(+)$, itici (-); uzak duran kadın için çekingen (-), normal (+); konuşurken karşısındakine dokunan kadın için samimi (+), dışa dönük (+), itici (-); somurtan kadın için sıkıcı (-), normal (+); ağlayan kadın için duygusal $(-)$, narin $(-)$, itici $(-)$; erkek gibi oturan için erkeksi (n), anormal (-); erkek gibi yürüyen kadın için erkeksi (n), anormal (-); el kol hareketleri erkek gibi olan kadın için erkeksi (n), kaba (-).

Erkek iletişim kaynağının beden diline yönelik kalıpyargılar ve bu kalıpyargıların duygu durumları ise şöyledir: yüksek sesle kahkaha atan erkek için kendini beğenmiş (-), kaba (-); sessizce gülümseyen erkek için kibar (+), normal (+); yakın duran erkek için samimi (+), anormal (-); uzak duran erkek için normal (+), çekingen $(-)$; konuşurken karşısındakine dokunan erkek için itici (-), anormal (-), samimi (+); somurtan erkek için sıkıcı (-), itici (-), kaba (-); ağlayan erkek için duygusal (-), sıkıcı $(-)$, itici (-); kadın gibi oturan erkek için kadınsı (n), itici (-); kadın gibi yürüyen erkek için anormal (-), itici (-), kadınsı (n); el kol hareketleri kadın gibi olan erkek için itici $(-)$, anormal $(-)$, kadınsı (-).

Dolayısıyla, yukarıda da her bir özellik üzerinden görülebileceği üzere, kişilerarası iletişim sürecinde kadın ve erkek iletişim kaynağının toplumsal cinsiyet kimliğine ilişkin kalıpyargıların farklılaştığını söylemek mümkündür. Diğer taraftan bazı uyarıcılara ilişkin en yüksek frekansı alan kalıpyargıların aynı olduğu da görülmektedir. Kadın ve erkek iletişim kaynağı için birbirinin aynı içeriğe sahip en yüksek frekansı alan kalıpyargılar şunlar olmuştur: konuşurken yakın duran kadın ve erkek, somurtan kadın ve erkek, ağlayan kadın ve erkek, kadın/erkek gibi oturan kadın/erkek.

$\mathrm{Bu}$ durumu belirli uyarıcılara ilişkin kalıpyargıların cinsiyet fark etmeksizin aynılaşması biçiminde açıklamak mümkündür. Çünkü belirli uyarıcıların cinsiyete bağlı olarak farklılaşamayacak derecede kesin toplumsal içerikleri bulunmaktadır. Örneğin; konuşurken yakın duran kadın ve erkek cinsiyet fark etmeksizin samimi, somurtan kadın ve erkek cinsiyet fark etmeksizin sıkıcı olarak kabul edilmektedir. Diğer yandan, bahsedilen bu kalıpyargılar için toplumsal cinsiyet kimliğinin önemsiz bir belirleyici olduğunu ifade etmek de yanlış olacaktır. Kadın ve erkek için en yüksek frekansı aynı olan uyarıcı ve sıfat eşleşmelerini takip eden daha düşük frekanslı eşleşmeler göz önünde bulundurulduğunda, toplumsal cinsiyet kimliğinin diğer kalıpyargı içerikleri üzerinde belirleyici olduğunu açıkça görmek olanaklıdır. 
Örneğin; konuşurken yakın duran kadın ve erkek iletişim kaynağı için samimi kalıpyargısı sonrasında kadın için normal, itici; erkek için anormal kalıpyargılarıyla nitelenmiştir. Somurtan kadın ve erkek iletişim kaynağı için sıkıcı kalıpyargısı sonrasında kadın için normal; erkek için itici ve kaba kalıpyargılarıyla birleşmiştir. Dolayısıyla, her ne kadar uyarıcıya ilişkin en yüksek frekansı alan ilk ifadeler aynı olsalar da, sonrasındaki ifadeler kişilerarası iletişim sürecinde karşılaşılan kalıpyargıların iletişim kaynağının toplumsal cinsiyetine bağlı olarak farklılaştığını bir kez daha gösterir niteliktedir.

Kişilerarası iletişim sürecinde kadın ve erkek iletişim kaynağının, çeşitli beden dili özellikleri üzerinden, toplumsal cinsiyet kimliğine ilişkin kalıpyargıları ortaya koyan bu çalışma, hem toplumsal cinsiyet kimliğine ilişkin kalıpyargıların kişilerarası iletişim sürecindeki önemini hem de söz konusu kalıpyargıların kişilerarası iletişim süreci için nasıl önemli iletişim engelleri olabileceğini ortaya koymayı amaçlanmıştır. $\mathrm{Bu}$ nedenle de gerçekleştirilen araştırmayla birlikte, kişilerarası iletişim sürecinde kaynağın toplumsal cinsiyet kimliğine bağlı olarak ortaya çıkan kalıpyargılar ve bu kalıpyargıların değerlendirenin toplumsal cinsiyet kimliğine bağlı olarak nasıl farklılıklar gösterdiği tespit edilmiştir. Ayrıca araştırma sonuçları kişilerarası iletişim sürecinde karşılaşılan kalıpyargıların sadece belirli bir cinsiyete yönelik olmadığını ya da belirli bir cinsiyet tarafından kalıpyargılı düşünceye sahip olunmadığını, söz konusu kalıpyargıların kadın ve erkek için ortak bir biçimde ve toplumun tüm üyeleri tarafından paylaşıldığını göstermesi bakımından da önem taşımaktadır.

Sonuç olarak, toplumsal cinsiyet kimliğine bağlı olarak ortaya çıkan kalıpyargılı düşünce, önyargılı tutum ve ayrımcı davranışın azaltılabilmesi öncelikle söz konusu kalıpyargıların bilinmesiyle mümkün olabilmektedir. Dolayısıyla gerçekleştirilen araştırma kapsamında bulgulanan kalıpyargı içeriklerinin, toplumsal cinsiyet kimliğine yönelik kalıpyargı, önyargı ve ayrımcılığın azaltılması için gerçekleştirilecek sonraki çalışmalarda da fayda sağlayacağı düşünülmektedir.

\title{
Notlar
}

${ }^{1} 2017$ yılı Türkiye İstatistik Kurumu verilerine göre Türkiye Devleti’nin nüfusu 79 milyon civarındadır (Türkiye İstatistik Kurumu, 2017).

\begin{abstract}
${ }^{2}$ Ancak kadın ve erkek iletişim kaynağının aynı sıralamayla aynı sıfatları aldıkları özellikler, kalıpyargı içeriklerinde cinsiyete dayalı bir farklılaşma göstermemesi dolayısıyla, soru formu dışında bırakılmıştır. Bu özellikler sırasıyla şunlar olmuştur: konuşurken göz teması kuran kadın/erkek için samimi, normal iddialı; konuşurken göz teması kurmayan kadın/erkek için kendine güvensiz, çekingen, içe dönük.
\end{abstract}

\section{Kaynakça}

Adaçay, F.R. (2014). Toplumsal Cinsiyet ve Kalkınma. Bursa: Ekin Yayınevi.

Akkoyun, F. (1983). Kişiliğin Projektif Testlerle Değerlendirilmesi. Ankara Üniversitesi Eğitim Bilimleri Fakültesi Dergisi, 16(2), 397-408.

Arıkan, R. (2004). Araştırma Teknikleri ve Rapor Hazırlama. Ankara: Asil Yayıncılık.

Best, D.L., Williams, J.E., Cloud, J.M., Davis, S., Robertson, L., Edwards, J., Giles, H. ve Fowles, J. (1977). Development of Sex-Trait Stereotypes Among Young Children in the United States, England, and Ireland. Child Development, 48(4), 1375-1384. 
Blank, P., Rosenthal, R., Snodgrass, S.E., DePaulo, B.M. ve Zuckerman, M. (1981). Sex Differences in Eavesdropping on Nonverbal Cues: Developmental Changes. Journal of Personality and Social Psychology, 41(2), 391-396.

Broverman, I.K., Vogel, S., Raymond, D.B., Clarkson, F.M. ve Rosenkrantz, P.S. (1972). Sex-Role Stereotypes: A Current Appraisal. Journal of Social Issues, 28(2), 5978.

Carli, L.L. (2001). Gender and Social Influence. Journal of Social Issues, 37(4), 725741.

Deaux, K. ve Lewis, L. (1984). Structure of Gender Stereotypes: Interrelationships Among Components and Gender Label. Journal of Personality and Social Psychology, 46(5), 991-1004.

Deaux, K. ve Major, B. (1987). Putting Gender Into Context: An Interactive Model of Gender-Related Behavior. Psychological Review, 94(3), 369-389.

Devine, P.G. ve Elliot, A.J. (1995). Are Racial Stereotypes Really Fading? The Princeton Trilogy Revisited. Personality and Social Psychology Bulletin, 21(11), 11391150.

Diekman, A.B. ve Eagly, A.H. (2000). Stereotypes as Dynamic Constructs: Women and Men of the Past, Present, and Future. Personality and Social Psychology Bulletin, 26, 1171-1188.

Dökmen, Ü. (2006). İletişim Çalışmaları ve Empati. Ankara: Sistem Yayıncılık.

Dökmen, Z. (2012). Toplumsal Cinsiyet Sosyal Psikolojik Açıklamalar. İstanbul: Remzi Kitapevi.

Eagly, A.H. and Johannesen-Schmidt, M.C. (2001). The Leadership Styles of Women and Men. Journal of Social Issues, 57(4), 781-797.

Eagly, A.H. ve Kite, M.E. (1987). Are Stereotypes of Nationalities Applied to Both Women and Men?. Journal of Personality and Social Psychology, 53(3), 451462.

Ersoy, E. (2009). Cinsiyet Kültürü İçerisinde Kadın ve Erkek Kimliği (Malatya Örneği). Fırat Üniversitesi Sosyal Bilimler Dergisi, 19(2), 209-230.

Gilbert, G.M. (1951). Stereotype Persistence and Change Among College Students. Journal of Personality and Social Psychology, 46(2), 245-254.

Gürüz, D. ve Eğinli, A.T. (2011). Kişilerarası İletişim Bilgiler-Etkiler-Engeller. İstanbul: Nobel Yayıncılı.

Güngör, N. (2011). İletişim Kavramlar Yaklaşımlar. Ankara: Siyasal Kitapevi.

Hall, J.A. (1978). Gender Effects in Decoding Nonverbal Cues. Psychological Bulletin, 85(4), 845-857.

Hamilton, D.L. (1979). A Cognitive-Attributional Analysis of Stereotyping. Advances in Experimental Social Psychology, 12, 53-84.

Harlak, H. (2000) Önyargılar: Psiko-Sosyal Bir İnceleme. İstanbul: Sistem Yayıncılık.

İsen, G. ve Batmaz, V. (2006). Ben ve Toplum. İstanbul: Salyangoz Yayıncılık.

İslamoğlu, A.H. (2003). Bilimsel Araştırma Yöntemleri. İstanbul: Beta Basım. 
Karlins, M., Coffman, T.L. ve Walters, G. (1969). On the Fading of Social Stereotypes: Studies in Three Generations of College Students. Journal of Personality and Social Psychology, 13(1), 1-16.

Katz, D. ve Braly, K. (1933) Racial Stereotypes of One Hundred College Students. Journal of Abnormal and Social Psychology, 28(3), 280-290.

Knapp, M.L. (1972). The Field of Nonverbal Communication: An Overview. C.J. Steward ve B. Kendall (Ed.) On Speech Communication: An Anthology of Contemporary Writings and Messages, New York: Holt, Rinehart \& Winston, 57-72.

Madon, S., Max, G., Aboufadel, K., Montiel, E., Smith A., Palumbo, P. ve Jussim, L. (2001). Ethnic and National Stereotypes: The Princeton Trilogy Revisited and Revised. Personality and Social Psychology Bulletin, 27I(8), 996-1010.

Matthews, G., Jones, D.M. ve Chamberlain, G.A. (1990). Refining the Measurement of Mood: The UWIST Mood Adjective Checklist. British Journal of Psychology, 81(1), 7-42.

Mutlu, E. (1998). İletişim Sözlüğü. İstanbul: Bilim \& Sanat Yayıncılık.

Rosenkrantz, P., Vogel, S., Bee, H., Broverman, I. ve Broverman, D.M. (1968). Sex-Role Stereotypes and Self-Concepts in College Students. Journal of Consulting and Clinical Psychology, 32(3), 287-295.

Somer, O. (1998). Türkiye'de Kișilik Özelliği Tanımlayan Sıfatların Yapısı ve Beş Faktör Modeli. Türk Psikoloji Dergisi, 42(13),17-32.

Spence, J.T., Helmreich, R. ve Stapp, J. (1975). Rating of Self and Peers on SexRole Attributes and Their Relationship to Self-Esteem and Conceptions of Masculinity and Feminity. Journal of Personality and Social Psychology, 32(1), 29-39.

Stangor, C. ve Lange, J.E. (1994). Mental Representations of Social Groups: Advances in Understanding Stereotypes and Stereotyping. M.P. Zanna (Ed) Advances in Experimental Social Psychology, New York, Academic Press, 375-416.

Stier, D. ve Hall, J. (1984). Gender Differences in Touch: An Empirical and Theorical Review. Journal of Personality and Social Psychology, 47(2), 440-459.

Türkiye İstatistik Kurumu, Adrese Dayalı Nüfus Kayıt Sistemi Sonuçları, 2017.

Williams, J.E., Satterwhite, R.C., ve Best, D.L. (1999). Pancultural Gender Stereotypes Revisited: The Five Factor Model. Sex Roles, 40(7-8), 513-525.

Williams, J.E. ve Best, D.L. (1982). Measuring Sex Stereotypes: A Thirty-Nation Study. California: Sage Publication.

Vatandaş, C. (2007). Toplumsal Cinsiyet ve Cinsiyet Rollerinin Algılanışı. Sosyoloji Konferansları, 35, 29-56. 
